\title{
SOSYAL MEDYADA KURUM KIMLIĞi YÖNETIMI: TÜRKIYE’NIN EN BÜYÜK 500 ŞIRKETi ÜZERINE BIR ARAŞTIRMA ${ }^{1}$
}

\author{
Gülçin SALMAN ${ }^{2}$ \\ Erhan EROĞLU ${ }^{3}$
}

\begin{abstract}
Öz
Sosyal medya hem bireyler hem de kurumlar açısından günümüzün en önemli iletişim araçlarından biri haline gelmiştir. İşletmeler, organizasyonlar, kurum ve kuruluşlar sosyal medyayı hedef kitleleri ile iletişim kurmada önemli bir araç olarak görmeye başlamıştır. Yapılan araştırmalar, kurumsal sosyal medya kullanımının her sene artmakta olduğunu ortaya koymaktadır. Ancak, sosyal medyada yer almaktan daha önemli olan bu ortamın nasıl kullanıldığıdır. Doğru bir şekilde yönetilmediğinde sosyal medya hesaplarının kurum imajına yarardan çok zarar getirdiği bilinmektedir. Sosyal medyanın sağladığı avantajlardan faydalanmak ve kurumsal imajı artırmak amacıyla kurumların kendilerini, diğer bir ifade ile kurumsal kimliklerini sosyal medyada doğru bir şekilde temsil etmeleri büyük önem taşımaktadır. Bu çalışma, kurumsal Facebook sayfalarında kurum kimliği unsurlarının ne düzeyde yansıtıldığını belirlemek amacıyla yapılmıştır. Bu amaç doğrultusunda, 2013 yılında Fortune tarafindan belirlenen Türkiye'nin en büyük 500 şirketi içerisinden sistematik örnekleme yöntemi ile alınan 55 şirketin resmi Facebook hesabı, içerik analizi yöntemi ile değerlendirilmiştir. Kurum kimliğini oluşturan kurum felsefesi, kurumsal tasarım, kurumsal iletişim ve kurumsal davranış boyutları ayrı ayrı incelenmiştir. Bulgular genel olarak değerlendirildiğinde, kurumsal tasarım ve kurumsal iletişim boyutlarının kurum felsefesi ve kurumsal davranışa göre daha fazla yansıtıldı ̆̆ tespit edilmiştir.
\end{abstract}

Anahtar Kelimeler: Sosyal medya, Facebook, kurumsal iletişim, kurum kimliği.

\section{CORPORATE IDENTITY MANAGEMENT ON SOCIAL MEDIA: A RESEARCH ON TURKEY'S 500 LARGEST COMPANIES' FACEBOOK PAGES}

\begin{abstract}
Social media platforms have become a significant tool for maintaining communications, not only for individuals, but also for corporations. Businesses, organizations and institutions began using social media in order to establish and maintain efficient communications with their target audience. Statistics show us that the percentage of corporate social media usage increases every year. However, what is more important than the amount of corporations using social media platforms is the way these platforms are managed by them. It is assumed that social media accounts bring disadvantages rather than advantages to corporate image when not managed properly. In order to take advantage of social media provides to corporations and improve the corporate image in positive way, it is crucial that corporations project and manage their identity appropriate ways. This research is done to bring a perspective on how big companies project their corporate identity on social media. For this purpose, 55 companies received from Turkey's largest 500 companies, stated by Fortune in 2013 by

${ }^{1}$ Bu makale, 2015 yılında Anadolu Üniversitesi Sosyal Bilimler Enstitüsü İletişim Tasarımı ve Yönetimi Anabilim Dalı’nda tamamlanan aynı isimli yüksek lisans tezinin özetidir.

${ }^{2}$ Arş. Gör. Anadolu Üniversitesi İletişim Bilimleri Fakültesi, gulcinsalman@anadolu.edu.tr

${ }^{3}$ Prof. Dr. Anadolu Üniversitesi İletişim Bilimleri Fakültesi, eeroglu@anadolu.edu.tr
\end{abstract}


systematic sampling, and their official Facebook accounts is analyzed by content analysis method. Corporate philosophy, corporate design, corporate communication and corporate behavior which are constitute corporate identity are analyzed individually. The result of the research suggest that corporate design and communication is projected more than corporate philosophy and behavior.

Key words: Social media, Facebook, corporate communication, corporate identity.

\section{Giriş}

İnternet ve bilgi teknolojilerindeki gelişmelerle birlikte, kurumsal iletişim eskiye oranla çok daha kolay bir hal almış, buna paralel olarak kurum kimliğinin yansıtılabileceği ortamlar da artmıştır. Web siteleri bu açıdan oldukça güçlü araçlar olarak ortaya çıkmıştır (Topalian, 2003: 1121). Zamanla internet teknolojilerindeki gelişmeler, web sitelerine alternatif ortamların ortaya çıkmasına zemin hazırlamıştır. Web siteleri çevrimiçi kurum kimliğini yansıtan ortamlar olsa da sosyal medya ile birlikte çevrimiçi kurum kimliği web sitesi içeriklerinin çok daha ötesine taşınmıştır (Walczak ve Gregg, 2009: 18). Çevrimiçi ortamlar, kurumlara hem düşük maliyetle hem de geleneksel medyaya ihtiyaç duymadan direkt olarak paydaşları ile etkileşim kurma imkanı yaratmıştır (Gilpin, 2010: 268).

Yeni iletişim teknolojileri ve bu kapsamda sosyal medya, bir kuruma karş1 olan algımızı geleneksel medya kadar etkilemektedir. Hangi kurum hakkında olumlu, hangi kurum hakkında olumsuz düşünmemiz gerektiği ile ilgili bilgileri ulaştırarak, kullanıcıları etki altında bırakmaktadır (Kadıbeşegil, 2007: 314). Kurum kimliğinin sağladığı tüm faydalar kurumların sosyal medya gibi mecralarda geniş kitlelere anlık olarak ulaşabilmeleriyle birlikte daha da geniş̧lemiş ve önem kazanmıştır. Tuna ve Tuna (2007: 97-98) kurumların faaliyetlerinin bir bölümünün artık sanal ortamlara taşındığını ve bu nedenle tüm aracıların devreden çıkabileceğini savunmuştur. Böyle bir ortamda, kurumların iyi tasarlanmış, sürekli güncellenen, kullanışlı internet sayfalarına ihtiyaçları olduğunu, aksi halde bu sayfaların kurumun imajına zarar veren bir unsur haline geleceğini iddia etmişlerdir. Teknolojideki gelişmelere bağlı olarak bütün kurumlar için sosyal medya araçlarında varlık göstermek ve onu diğerlerinden ayırt eden kurum kimliğini sosyal medya hesaplarına taşımak, kurumların paydaşları ile iletişimi açısından büyük önem taşımaktadır. 


\section{Kurum Kimliği Kavramı}

Kurumlar da bireylerin sahip olduğu gibi birer kimliğe sahiptir. Bu kimlik, kurumların birbirlerinden ayrılmasına yardımcı olur. Nasıl ki, her insanın bazı yönlerden kendine has özellikleri varsa, kurumlar da aynı şekilde kendine has ve taklit edilemez özelliklere sahiptir (Dolphin, 1999: 43). Kurumlar her gün gerçekleştirdikleri faaliyetlerinde kimliklerinin bir kısmını veya tamamını iç ve dış paydaşlarına sunmaktadır. Kurumsal kimlik, iletişim uzmanları tarafından bir plan dahilinde ve çerçevesinde yaratılan ve kodlamalar yoluyla iletilen bir yapıya sahiptir (Dolphin, 1999: 43). Kurum kimliği paydaş gruplarına yansıtılırken, kullanılan kodlamalar kurumun nasıl algılanmak istediğini temsil eder (Markwick ve Fill, 1997: 397).

Kurum kimliği kurumun kendisini nasıl tanımladığı ve iç ve diş hedef kitlelerine nasıl tanıtmak, göstermek ve ifade etme istediği ile ilgilidir. Öz değerlerinin, felsefesinin ve stratejisinin görsel ve davranışsal ortamda iletilmesidir (Bick vd., 2003: 839). Diğer bir ifade ile kurumun kişiliğinin, onu diğerlerinden farklılaştıran özelliklerinin somutlaşması ve bu yolla kurum tarafından alıcılara iletilmesidir. Kimlik genel olarak dört unsurdan meydana gelmektedir. Bunlar kurumda çalışanların ve kurumun davranışları, kurumun iletişim biçimleri, felsefesi ve görsel tasarım unsurlarıdır. Bu unsurların bir kuruma özgü kullanımı o kurumun kimliğini meydana getirmektedir (Okay, 2013: 25-26).

\subsection{Kurum Kimliğinin Unsurları}

Güçlü ve başarılı bir kimlik oluşturabilmek için, "kurumsal kimlik karması" olarak adlandırılan kurum kimliği unsurlarının hepsine gereken özeni göstermek gerekmektedir (Theaker, 2006: 137).

Kurum felsefesi, kurum kimliğinin özünü oluşturduğu ve bu nedenle kimliğin bütün unsurlarını etkilediği için büyük bir öneme sahiptir. Kurum felsefesi üst düzey yöneticiler tarafından belirlenmektedir. Kurum felsefesini "kurumun gerçekte ne olduğu" olarak ifade eden Markwick ve Fill (1997: 399), kimliğin ortaya çıkması için felsefenin bir temel oluşturduğunu ve açık ve net bir biçimde kurum tarafindan tanımlanmasının birincil öncelik olduğunu vurgulamışlardır. Kurum felsefesi 
kurumun misyonu, vizyonu, hedefleri, değerleri, tarihçesi, kuruluş tarihi, kurucusu gibi unsurlardan oluşmaktadır. Bu unsurların hepsinin kurum kimliğini belirlemede ve iletmede ayrı rolleri bulunmaktadır (Melewar ve Karaosmanoğlu, 2006).

Kurumsal tasarım, kurumun ilk bakışta dikkat çeken görsel unsurlarıyla ilgili olduğu için büyük önem taşımaktadır. Kurumsal kimlik tasarımı, kurumun sahip olduğu özelliklerin tasarım elemanlarının en etkili biçimde kullanılarak görselleştirilmesidir. Kurumsal tasarım; logo, yazı tipi, slogan, renkler gibi görsel iletişim unsurlarını, kuruma ait fabrika veya binalar gibi çevresel unsurları (van den Bosch vd., 2006: 871) ve müşterilerin tükettiği ürün ya da hizmetleri farklılaştırma amacını taşıyan tasarım unsurlarını ifade eden ürün tasarımını kapsayan bir bütündür.

Kurumsal iletişim, kuruluşların çeşitli biçimlerde hedef gruplarıyla iletişim içerisine girme çabasıdır. Bu süreçte kurumların kullandığı bütün iletişim yöntemleri ve aktiviteleri kurumsal iletişim kavramı içerisinde değerlendirilmektedir. Kısaca kurumsal iletişim, bir kurum ve hedef kitlesi arasında gerçekleşen bütün sözlü, sözsüz, yazılı, görsel, işitsel iletişim biçimlerini kapsamaktadır (Okay, 2013: 153) ve kimliği imaja dönüştürme süreci olarak da ifade edilebilir (Dolphin, 1999: 44). Kurumsal iletişim, belirli amaçlar doğrultusunda planlı bir şekilde başlatılan ve sürdürülen iletişim ise kontrol edilebilir, kurumun iletişim planları dışında kasti olmayan bir şekilde paydaşlarının algılarını etkilemesi sonucu ortaya çıkarıyorsa kontrol edilemeyen iletişim olarak tanımlanır (Melewar ve Karaosmanoğlu, 2006: 850). Kurum hakkındaki söylentiler, tüketicilerin kurumla veya ürünleriyle ilgili yaptıkları yorumlar veya kurum tarafından bilinçsiz bir şekilde gönderilen mesajlar buna örnektir. Özellikle sosyal medya gibi çift yönlü iletişimin yoğun bir biçimde yaşandığı ve iletilerin çok hızlı bir biçimde yayılabildiği bir ortamda kontrol edilebilen ve edilemeyen iletişim süreçlerinin iyi dengelenmesi kritik önem taşımaktadır.

Kurumsal davranış, "kurumsal tutumlar sonucu planlı veya kendiliğinden ortaya çıkan kurumsal eylemlerin toplamı” olarak tanımlanmaktadır (Melewar, 2003: 195). Bu eylemler iç ve dış ilişkilerde gözlemlenebilir. İç ilişkilerdeki yansımalarına örnek olarak, "işe başlama dönemindeki davranış, yönetici konuşması, iletişim tarzı ve kriz çatışma davranışı" verilebilir. Dış ilişkilerdeki yansımalarının örnekleri 
"seçme ve işe başvurma yöntemi, müşteriyle konuşma tarzı, şikayetleri ele alma tarzı, kamuoyunda ortaya çıkış ve pazar ortaklarına karşı davranıştır” (Kiessling ve Spannagl, 1996'dan aktaran Okay, 2013: 47).

van Riel ve Fombrun'a göre (2007: 68) davranış bir kurumun kimliğini ifade etmesindeki en önemli unsurdur çünkü hedef kitleler kurumu en sonunda gerçekleştirdiği eylemlere göre değerlendireceklerdir. Kısaca, bir kurumun paydaşları ile iletişime geçme imkanına sahip olduğu her ortamda kurumsal davranışın ortaya çıkacağı söylenebilir. Kurumun sosyal medyadaki davranışı yoluyla nasıl kimliğini yansıtabileceğini soran Kostamo (2013: 67) bir yöneticiden şu cevabı almıştır: "Davranış - yani şirketin bütün varlığı: şirketin ulaşılabilir olup olmaması, cevabı bir saat ya da bir hafta içinde vermesi ve dinleyip dinlemediği. Bütün sosyal medya varlığı davranış ile ilgilidir.”

Kurum kimliği yapısının bir parçası olan bu unsurlar kimliği meydana getirerek kurum imajı ve kurum itibarı oluşumunda önemli bir rol oynamaktadır.

\subsection{Kurum Kimliği, İmajı ve İtibarı Arasındaki ỉiş̧ki}

Kurumun kendini sunuş biçimlerinin toplamı onun kimliği olarak adlandırılır. Farklı izleyicilerin kurumla ilgili algıları ise imaj olarak adlandırılmaktadır (Olins, 1995: 3). Bu algılar, kurumun kimliğini planlı ve bilinçli bir biçimde sunuşundan bilerek veya çalışanlar ve medya gibi diğer taraflarca yapılan yorumlardan tesadüf eseri oluşabilir (Markwick ve Fill, 1997: 398). Artık elektronik ortamlarda gerçekleştirilen faaliyetler de kurum imajının önemli belirleyicilerinden sayılmaktadır. Kurumun internette sahip olduğu sayfanın tasarımı, sayfanın içeriği, şirket ve ürünlerle ilgili paylaşılan bilgiler, şirket ve internet kullanıcıları arasındaki etkileşimler kurum imajını belirlemede rol oynar. Şirketler tarafından paylaşılmayan ve internet ortamında o şirketle ilgili bulunan diğer bütün bilgiler de aynı şekilde imajı belirlemede rol sahibidir (Walczak ve Gregg, 2009: 18). Birbirlerine yakın kavramlar olan imaj ve itibar bazen birbirlerinin yerine kullanılmaktadır. Aralarındaki fark, imaj daha değişken ve kısa sürede oluşan bir yapıya sahipken itibarın, oluşması için uzun süre gerektiren ve daha sabit bir yapıya sahip olmasıdır. Buna göre, iyi planlanan bir kimlik kısa sürede olumlu bir imaja, uzun sürede ise iyi 
bir itibara yol açabilmektedir. Özelikle çevrimiçi ortamlarda bir bilgi çok fazla sayıda birey ve kurumun erişimine açık olduğu ve çok kısa sürede geniş kitlelere yayılabildiği için kurumların, çevrimiçi ortamları kullanmaları konusunda bazı önemli noktalara dikkat etmeleri kurumsal iletişimin başarısı açısından önemlidir.

\section{Sosyal Medya ve Kurumsal İletişim}

Genel bir ifadeyle, sosyal medya, ağ tabanlı araçlar ve yazılımlarla, kullanıcıların çevrimiçi olarak bir araya gelerek, tartışarak, paylaşarak, iletişim kurarak sosyal etkileşim içine girdiği ortamlara verilen bir şemsiye tanımlamadır. $\mathrm{Bu}$ iletişim ve etkileşim metin, fotoğraf, video, ses gibi çeşitli biçimlerde içeriklerin üretimiyle ve paylaşımıyla gerçekleşmektedir. (Ryan, 2014: 151).

Kurumlar internet ve sosyal medyanın iletişim faaliyetlerinde oynadığı önemli rolü fark etmişlerdir. Alternatif bir iletişim ve pazarlama ortamı sunan bu araçların çok daha düşük maliyetli ve yüksek etkiye sahip olmasının sağladığı avantajlardan faydalanarak, hedef kitlelerle etkileşim için geleneksel kanallardan daha çok bu mecralara yönelmektedirler (Castronovo ve Huang, 2012: 117). Amerika'da 2013 yılında Fortune 500 şirketlerine yönelik sosyal medya kullanımı araştırmasının bir önceki yıla göre sonuçları değerlendirildiğinde sosyal medya kullanımının bu şirketler arasında önemli biçimde arttığı ortaya çıkmıştır (Barnes vd., 2013: 8).

Başarılı bir sosyal medya iletişimi için, sunulan hizmetin tipi ve kurumun amaçları gözetilerek bir sosyal medya stratejisi belirlemek önemlidir. Kurumlar Facebook ve Youtube gibi sosyal medya araçlarını hangi amaçlarla ve nasıl kullanacakları ile ilgili planları kurumun özüne uygun bir biçimde oluşturmalıdır (Kaplan ve Haenlein, 2010: 66). Diğer bir ifade ile kurumsal kimliğin sosyal medya hesaplarında nasıl yönetileceği ve yansıtılacağı kurumların bu hesapları kullanmaya başlamadan önce cevaplaması gereken bir sorudur.

Bu çalışmada incelenen sosyal medya sitesi Facebook ise dünya genelinde bir milyarın üzerinde kullanıcısı olan bir sosyal ağ sitesi olarak hizmet vermektedir. Facebook aracılığı ile kişisel etkileşimin ötesinde kullanıcıların kurum, şirket veya organizasyonlarla da etkileşim kurması mümkündür. Kullanıcılar bir kurumun 
Facebook sayfasını beğenerek ona olan ilgisini göstermekte ve kurumla ilgili olarak çeşitli bilgi ve gelişmeleri takip etme olanağı bulabilmektedir (Safko, 2012: 32-33). Aynı şekilde kurumlar da paydaşları ile ilgili büyük bir veri yığınına erişebilme ve onlarla daha iyi etkileşim kurma, kurumsal bilinirlik ve imaj1 güçlendirme, mesajlarını ve kimliğini istediği gibi yönetebilme şansına sahiptir (Postman, 2009: 35).

\section{Yöntem}

Bu çalışmanın amacı, kurumların, paydaşlarıyla iletişim kurduğu bir mecra olan kurumsal Facebook hesaplarında kurum kimliği unsurlarını ne düzeyde yansıttıklarını ortaya çıkarmaktır. Bu amaç doğrultusunda çalışma evreni olarak, 2013 yılında Fortune tarafından belirlenen “Türkiye'nin En Büyük 500 Şirketi” seçilmiştir. Evrenin bu şekilde belirlenmesinin sebebi, Türkiye'deki en büyük şirketleri içermesi ve bu listede yer alan şirketlerin hepsinin kurum kimliği unsurlarının tamamına sahip olduğunun düşünülmesidir. İncelemeye yalnızca resmi Facebook sayfaları dahil edilmek istendiği için, sırayla 500 şirketin web sayfalarına girilerek Facebook'a bağlantı verip vermediklerine bakılmıştır. Web sayfasında çalışan bir Facebook bağlantısı veren 219 şirket Fortune 500 sıralamasına göre sıralanarak yeni bir liste elde edilmiştir. Örneklem bu listeden "sistemli rastsal örnekleme” kullanılarak belirlenmiştir. Sistemli rastsal örneklem, belli bir özelliğe göre sıralanmayan evrenin numaralandırılması ve belirlenen seçim aralığına göre örneklemin alınması yöntemidir (Erdoğan, 1998: 88). Bu örnekleme türünde öncelikle örneklem büyüklügüne karar verilir ve buna göre bir seçim aralığ belirlenir. Bu araştırmada yeni oluşturulan listenin $\% 25$ 'i örneklem büyüklüğü olarak belirlenmiş ve buna göre 1. numaralı şirketten başlayarak her 4. şirket örnekleme dahil edilmiştir.

Yansıtılan kurumsal kimlik şirketin basıl1, görsel, görüntülü ve web üzerinden gerçekleştirdiği iletişim yoluyla ortaya çıkmaktadır. Çevrimiçi ortamlarda yansıtılan kurum kimliğini ölçmek için kullanılacak en güçlü yöntem içerik analizidir (van Riel ve Fombrun, 2007: 89-90). İçerik analizinin amacı, sözel ve sözel olmayan sembolik iletişim içeriklerini betimlemenin yanı sıra, görünenden görünmeyene diğer bir ifadeyle mevcut olan içerikten mevcut olmayan bağlama yönelik çıkarım yapmaktır 
(Gökçe, 2001: 7). Araştırmacı, içerik analiziyle birçok metnin (iletişim ortamı görevi gören her türden yazılı, görsel, sözel öğe) içeriğini karşılaştırabilir ve onu tablolar gibi nicel tekniklerle analiz edebilir (Neuman, 2008: 466). Bu nedenle örneklemi oluşturan 55 şirketin Facebook sayfaları kurum kimliğinin unsurları olan kurum felsefesi, kurumsal tasarım, kurumsal iletişim ve kurumsal davranış bağlamında içerik analizi yöntemi ile analiz edilmiştir. Bu dört unsurun alt unsurları sayfalarda hiç bulunmuyorsa yok, bir kez paylaşılması durumunda düşük, birden fazla paylaşılması durumunda yüksek olarak kodlanmıştır.

Araştırma verileri örnekleme dahil olan şirketlerin Facebook’taki resmi sayfalarından toplanmıştır. Facebook hesaplarındaki profil ve kapak fotoğrafları, albümleri, videoları, hakkında bölümleri, uygulama kullanımları, beğenileri, sayfadaki takipçilerin iletileri, fotoğraf ve video paylaşmaya verdikleri izin, özel mesaj göndermeye verdikleri izin, zaman tüneli (iletiler) ve iletilere takipçiler tarafından yapılan yorumlar ve bunlara şirketlerin verdikleri cevaplar incelenmiştir. Şirketlerin Facebook hesaplarındaki iletilerden araştırmanın gerçekleştirildiği tarihteki son dört aylık (1 Nisan - 1Temmuz 2015) kısmı analize dahil edilmiştir. Sosyal medya aracı olarak Facebook'un seçilmesinin nedeni en çok kullanıcı sayısına sahip olması, Fortune 500 listesindeki şirketlerin en fazla kullandığı sosyal medya aracı olması ve kurum kimliği öğelerini yansıtmak için diğer sosyal medya araçlarına göre daha fazla olanak sunmasıdır.

Araştırma sorularını yanıtlayabilmek amacıyla, farklı kategoriler ve alt kategorilerden oluşan bir kodlama formu geliştirilmiştir. Bu form, araştırma amaçları doğrultusunda, alanyazındaki bilgilerden ve ilgili araştırmaların kodlama formlarından yararlanılarak araştırmacı tarafından geliştirilmiştir. Kodlama formunun içerik geçerliğini belirlemek için, araştırma konusunda uzman üç kişinin görüşüne danışılmıştır. Yapılan değerlendirmeler sonucunda kodlama formuna son hali verilmiştir.

Çalışma için gerekli olan verilerin elde edilmesi amacıyla yapılan içerik analizi kodlamaları araştırmacı tarafından gerçekleştirilmiştir. Kodlamanın güvenilir ve tarafsız bir biçimde yapılıp yapılmadığını anlamak için güvenirlik testi uygulanmıştır. Kurumlara ait Facebook sayfalarından rastgele seçilen 25 tanesi başka 
bir kodlayıcı tarafından kodlanmış ve iki kodlama arasındaki uyuma bakılmıştır. Poindexter ve McCombs (2000: 203) kodlayıcılar arasındaki uyumun en az \%80 olması gerektiğini, bu sayının altındakilerin güvenilir olmadığını belirtmişlerdir. Kodlama formundaki her kategori için kodlayıcılar arasındaki uyum ayrı ayrı hesaplanmış ve her kategoride \%80'in üzerinde bir uyum yakalanmıştır.

\section{Bulgular ve Yorum}

Araştırma bulguları kurum felsefesi, kurumsal tasarım, kurumsal iletişim ve kurumsal davranış boyutlarına göre ayrı başlıklar altında incelenmiştir.

\subsection{Kurum Felsefesi ile İlgili Bulgular}

Kurum felsefesinin Facebook sayfalarında nasıl yansıtıldığına yönelik olarak sekiz farklı kurum felsefesi ile ilgili unsurunun sayfada ne düzeyde bulunduğu analiz edilmiştir. Bu unsurlar kurum hakkında genel bilgi, çalışma alanları hakkında bilgi, kurucu/yönetici hakkında bilgi, kurumsal hedefler ve değerler, vizyon ve misyon, kurumun tarihçesi ve kuruluş tarihi, yöneticinin mesajı ve yöneticinin fotoğraf ve videolarından oluşmaktadır. Bu unsurların yansıtılma düzeyi Tablo 1'de verilmiştir.

Tablo 1. Kurum felsefesi ile ilgili unsurların yansıtılma düzeyi

\begin{tabular}{|l|c|c|c|c|}
\cline { 2 - 5 } \multicolumn{1}{c|}{} & YÜKSEK & DÜŞÜK & YOK & TOPLAM \\
\hline Kuruluş tarihi/tarihçe & 25 & 27 & 3 & 55 \\
\hline Misyon / vizyon & 4 & 23 & 28 & 55 \\
\hline Hedefler/değerler & 2 & 10 & 43 & 55 \\
\hline Kurum hakkında bilgi & 26 & 17 & 12 & 55 \\
\hline Çalışma alanları & 40 & 7 & 8 & 55 \\
\hline Yönetici hakkında bilgi & 4 & 7 & 44 & 55 \\
\hline $\begin{array}{l}\text { Yöneticilerin fotoğraf ve } \\
\text { videoları }\end{array}$ & 20 & 11 & 14 & 55 \\
\hline Yöneticinin mesajı & 5 & 4 & 46 & 55 \\
\hline
\end{tabular}

Faceboook sayfalarında en fazla yer verilen kurum felsefesi unsuru kurumun kuruluş tarihidir. 3 şirket hariç diğer 52 şirket, kuruluş tarihine sayfalarında yer ver vermiştir. Kuruluş tarihinin yanı sıra kurumda gerçekleşen önemli olayların yıl yıl ayrıntılı olarak belirtildiği tarihçeye yer veren şirket sayısı 25'tir. İkinci olarak, 
çalışma alanları hakkında bilgiye 47 sayfada yer verilmiş 8 sayfada yer verilmemiştir. 40 sayfada çalışma alanlarının hepsinden bahsedilirken, 7 sayfada çalışma alanlarının bir kısmına değinilmiştir. Üçüncü olarak, kurum hakkında bilgi 43 sayfada yer alırken, (26 sayfada yüksek, 17 sayfa düşük düzeyde) 12 sayfada bulunamamıştır.

Şirketlerin misyon ve vizyon cümlelerine yer verme oranları yarı yarıyadır. Misyon veya vizyon cümlesini Facebook sayfalarına yazan şirket sayısı 27'dir. Bu şirketlerden 4 tanesi hem misyon hem de vizyon cümlesini yazmış, 2 tanesi sadece vizyon cümlesini, 21 tanesi sadece misyon cümlesini yazmıştır. Şirketlerin felsefelerini ve kimliklerini yansıtmada en önemli unsurlardan diğeri olan kurumsal hedefler ve değerlere sayıca az şirketin yer verildiği görülmüş ve bu durum şirketler açısından önemli bir eksiklik olarak değerlendirilmiştir. Şirketlerin sadece 2 tanesi kurumsal hedefler ve değerlerine sayfalarında yer vermiş, 6 tanesi yalnızca hedeflerine, 4 tanesi ise yalnızca değerlerine yer vermiştir.

Facebook geniş kitlelere ulaşmak ve istenen bilgileri aktarmak için oldukça önemli bir araçtır. Şirketlerin yaptıkları iş, kuruluş tarihi ve genel olarak kendileri hakkında yüksek düzeyde bilgi vermiş olmaları, kendilerini geniş kitlelere tanıtma isteğiyle ilgili olabilir. Şirketlerin Facebook'u şirket hakkında genel bilgileri iletmek amacıyla kullandıkları söylenebilir. Ancak, kurum kimliğinin temelini oluşturan kurum felsefesi ve kurum felsefesinin en önemli unsurları olan misyon, vizyon, hedefler, değerler ve yöneticilerle ilgili bilgilere yeterince yer verilmemiş, bu unsurlara Facebook sayfalarında daha düşük oranlarda rastlanmıştır.

Kurum felsefesini Facebook sayfalarında yansıtma durumlarını belirlemek amaciyla incelenen 8 unsur üzerinden yapılan kodlamaya $(0=$ yok, $1=$ düşük, $2=$ =üksek) göre, bu kategoride en fazla 16 puan alınabilmektedir. Ancak 8 unsuru birden yüksek seviyede yansıtan bir şirket örneklem içerisinde çıkmamıştır. En yüksek puan 13, en düşük puan 0'dır. 55 şirketin bu kategorideki ortalaması, 16 üzerinden 6,5 olarak tespit edilmiştir. Genel olarak bakıldığında, şirketlerin kurum felsefesi unsurlarına Facebook sayfalarında yeterince yer vermediğini söylemek mümkündür. 


\subsection{Kurumsal Tasarım ile ilgili Bulgular}

Kurumsal tasarıma ilişkin değişkenler iletişim tasarımı ve ürün ve çevre tasarımı başlığı altında incelenmiştir. Logo, amblem, slogan ve kurumsal renkler kurumun iletişim tasarımı boyutlarını oluşturmaktadır. Kurumsal iletişim tasarımı unsurlarının Facebook sayfalarında ne düzeyde yansıtıldığı ile ilgili bulgular Tablo 2'de gösterilmektedir.

Tablo 2. Kurumsal Illetişim Tasarımı Unsurlarının Yansıtılma Düzeyi

\begin{tabular}{|l|c|c|c|c|}
\cline { 2 - 5 } \multicolumn{1}{c|}{} & YÜKSEK & DÜŞÜK & YOK & TOPLAM \\
\hline Logo & 51 & 2 & 2 & 55 \\
\hline Amblem & 7 & 4 & 44 & 55 \\
\hline $\begin{array}{l}\text { Kurumsal } \\
\text { Renkler }\end{array}$ & 31 & 13 & 11 & 55 \\
\hline Slogan & 15 & 11 & 29 & 55 \\
\hline
\end{tabular}

Kurumsal iletişim tasarımı unsurların sayfalarda en fazla yer verilen unsur diğerlerine göre büyük bir farkla logo olmuştur. Logolar 51 sayfada yüksek, 2 sayfada düşük oranda yansıtılmıştır. Yalnızca 2 kurum Facebook hesabında logosuna yer vermemiştir. Logonun bu derece yüksek bir düzeyde yansıtılmasının nedeni olarak, Facebook'un profil fotoğrafı özelliği gösterilebilir. Profil fotoğrafı, şirketlerin takipçiler tarafından kolayca ayırt edilmesinde önemli bir araçtır. Profil fotoğrafı, bir Facebook sayfasına girildiğinde en çok bakılan alanlardan bir tanesi ve kullanıcıların ana sayfasında şirketin bir iletisi yer aldığında, şirket ismi yanında görünen tek unsurdur. Paylaşılan içeriklerdeki görsellerde de logoya sıklıkla yer verildiği görülmüştür. Buradan, şirketlerin logolarının görünümüne ne kadar önem verdiği anlaşılmaktadır. Sayfalarda en az yer verilen kurumsal iletişim tasarımı unsuru amblemdir. Amblem kullanımın düşük düzeyde çıkması logonun yüksek düzeyde kullanımı ile açıklanabilir. 7 şirketin profil fotoğrafinda logosu yerine yalnızca amblemini kullanmayı tercih ettiği görülmüştür.

Tablo 3. Çevre ve Ürün Tasarımı Unsurlarının Yansıtılma Düzeyi

\begin{tabular}{|l|l|l|l|l|}
\hline YÜKSEK & DÜŞÜK & YOK & TOPLAM \\
\hline
\end{tabular}




\begin{tabular}{|l|c|c|c|c|}
\hline $\begin{array}{l}\text { Şirket binasının } \\
\text { fotoğrafları/videoları }\end{array}$ & 20 & 4 & 31 & 55 \\
\hline $\begin{array}{l}\text { Çalışma alanlarının } \\
\text { fotoğrafları/videoları }\end{array}$ & 23 & 9 & 23 & 55 \\
\hline Çalışanların fotoğrafları/videoları & 23 & 10 & 22 & 55 \\
\hline Ürün-hizmet fotoğrafları/videoları & 46 & 5 & 4 & 55 \\
\hline
\end{tabular}

Sayfalarda yer verilen çevre tasarımı unsurlarına dair oranların üç değişken için dengeli bir dağılım gösterdiği söylenebilir (Tablo 3). Şirket binasına, çalışanlara ve çalışma alanlarına fotoğraf ve videolarda yer verme düzeyleri birbirine yakın bulunmuştur. Çevre tasarımına oranla ürün/hizmete dair görsellere yer verilme oranı oldukça yüksektir. Kurumların ürettiği ürünler veya verdikleri hizmetlerle ilgili fotoğraf ve videolara ait bu yüksek yansıma oranını, Facebook hesaplarını ürünleri/hizmetleri için önemli bir tanıtım mecrası olarak gördükleri şeklinde yorumlamak mümkündür.

Şirketlerin kurumsal tasarım unsurlarını Facebook sayfalarında yansıtma durumlarını belirlemek amacıyla incelenen 8 unsur üzerinde yapılan kodlamaya $(0=$ yok, 1=düşük, 2=yüksek) göre, bu kategoride en fazla 16 puan alınabilmektedir. Sadece bir şirket bu unsurların hepsine sayfasında yüksek düzeyde yer vererek tam puan almıştır. En düşük puanı alan şirketin puanı 4'tür. 55 şirketin bu kategorideki ortalamas 18,9 olarak bulunmuştur.

\subsection{Kurumsal İletişim ile Ilgili Bulgular}

Kurumsal iletişim başlığı altında şirketlerin Facebook sayfalarında telefon, eposta adresi gibi diğer iletişim kanallarının yer alma düzeylerine, sayfada bağlantı verilmiş diğer sosyal medya araçlarının ne olduğuna, iletilerde kullanılan içerik türlerinin (fotoğraf, video, etiket, bağlantı) oranlarına bakılmıştır. Ayrıca, Facebook'un kullanıcılara sağladığı araçların ne düzeyde kullanıldığı ve ne sıklıkla ileti paylaşıldığı analiz edilmiştir. Hangi iletişim kanallarına yer verildiği Tablo 4'te gösterilmektedir.

Tablo 4. Diğer İletişim Kanallarına Yer Verilme Düzeyi

\begin{tabular}{l|l|l|l|l|}
\cline { 2 - 4 } & YÜKSEK & DÜŞÜK & YOK & TOPLAM \\
\hline
\end{tabular}




\begin{tabular}{|l|c|c|c|c|}
\hline Sosyal medya & 16 & 18 & 21 & 55 \\
\hline Telefon No & 15 & 24 & 16 & 55 \\
\hline Adres & 16 & 12 & 27 & 55 \\
\hline E-posta & 4 & 21 & 30 & 55 \\
\hline Web sitesi & 54 & - & 1 & 55 \\
\hline
\end{tabular}

En fazla yer verilen iletişim kanalının web sitesi adresi olduğu görülmektedir. Yalnızca bir şirkette web sitesi adresinin bilgisi bulunmamaktadır. İkinci olarak telefon numaralarına, üçüncü sırada sosyal medya hesaplarına, dördüncü sırada adres bilgilerine son olarak da e-posta adresine yer verilmiştir.

Bağlantı verilen diğer sosyal medya araçları ise sırası ile şu şekildedir: Twitter (28), Youtube (13), Instagram (12), LinkedIn (8), Pinterest (5), Google + (3), Periscope (1), Vimeo (1), Vkontakte (1). Türkiye'deki sosyal medya araçlarının kullanıcı sayısı açısından sıralaması ile bağlantı verilen sosyal medya araçlarının sıralaması arasında bir paralellik bulunduğu dikkat çekmektedir. Facebook'tan sonra en fazla kullanıcısı olan Twitter, şirket sayfalarında da en fazla yer alan sosyal medya hesabı olmuştur.

Diğer iletişim kanallarına yer verilme düzeyine bakıldığında, ön plana web sitesinin çıktığı görülmüştür. Neredeyse bütün şirketler web sitelerine sayfalarında birden fazla bölümde yer vermiştir. Hem sayfaya girildiğinde görülecek biçimde hem iletilerde hem de takipçilerin iletilerine şirketlerin verdiği cevaplarda en fazla yer alan iletişim kanalı web sitesi olmuştur. Bu durum, kurumsal iletişimde şirketlerin en fazla önem verdiği kanal olarak web sitelerini görmeleri şeklinde yorumlanabilir.

Facebook sayfasında kullanıma sunulmuş bazı özellikler şirketler ve takipçileri arasındaki çift yönlü iletişimi mümkün kılmaktadır. Bu özellikler, kullanıcıların sayfalarda fotoğraf ve video paylaşımında bulunabilmeleri, şirkete doğrudan mesaj yollayabilmeleri ve şirketin Facebook sayfasında yazılı bir ileti paylaşabilmeleridir. Bu özellikler sayfa yöneticileri tarafından sınırlandırılabildikleri gibi tamamen kullanım dışı da bırakılabilmektedir. Şirketlerin bu özellikten ne ölçüde faydalanmaya açı oldukları Tablo 5’te gösterilmektedir. 
Tablo 5. Çift Yönlü İletişime Açık Olma Düzeyleri

\begin{tabular}{|l|c|c|c|}
\cline { 2 - 4 } \multicolumn{1}{c|}{} & VAR & YOK & TOPLAM \\
\hline ileti paylaşmaya izin & 14 & 41 & 55 \\
\hline $\begin{array}{l}\text { Fotoğraf/video } \\
\text { paylaşmaya izin }\end{array}$ & 9 & 46 & 55 \\
\hline $\begin{array}{l}\text { Özel mesaj } \\
\text { göndermeye izin }\end{array}$ & 51 & 4 & 55 \\
\hline
\end{tabular}

Şirketlerin en fazla özel mesaj yolu ile takipçilerinin kendilerine ulaşmasını istediği görülmektedir. Facebook sayfasında bütün katılımcılara açık bir şekilde ileti ya da fotoğraf paylaşılması çok fazla tercih edilmemiştir. Kurumlar takipçileri ile iletişim halinde kalmayı tercih ederken, sayfada paylaşılabilecek içeriğin kontrol sorumluluğundan kaçınarak bu kanalları tamamen devre dışı tutmayı tercih etmiş görünmektedir.

Kurumların son 4 ay içerisinde ne kadar ileti paylaştıkları incelenmiş, 34 gibi büyük bir kısmının yüksek düzeyde (haftada 3 veya daha fazla) ileti paylaştı̆̆ görülmüştür. 18'i düşük düzeyde (haftada 3'ten az) ileti paylaşmaktadır. 3 tanesinin son 4 ay içerisinde hiç ileti paylaşmadığı tespit edilmiştir.

Kurumların sosyal ağları kullanırken dikkat etmesi gereken durumların başında sosyal medya hesaplarının güncelliğini korumak gelmektedir. Herhangi bir sosyal ağda şirketlerin hesap açmış olması orada bir varlık gösterdiği anlamına gelmemektedir. Önemli olan bu hesapların doğru ve sistemli bir şekilde yönetilmesidir. Kurumsal bir hesap açıp daha sonra kullanılmaması kadar çok fazla kullanılması da kurum imajına zarar verebilir. Bu noktada 55 şirketten hiç birinin olumsuz anlamda yoğun bir biçimde ileti paylaşmadığı söylenebilir. Bu nedenle, bu oranlar şirketlerin geneli açısından olumlu olarak yorumlanmıştır. Paylaşılan iletilerin içeriklerine Tablo 6'da yer verilmiştir.

Tablo 6. Paylaşılan İletilerin İçerikleri

\begin{tabular}{|l|c|c|l|c|}
\cline { 2 - 5 } \multicolumn{1}{c|}{} & YÜKSEK & DÜŞÜK & YOK & TOPLAM \\
\hline Fotoğraf & 48 & 7 & - & 55 \\
\hline Bağlantı & 42 & 4 & 9 & 55 \\
\hline Video & 30 & 13 & 12 & 55 \\
\hline
\end{tabular}




\begin{tabular}{|l|l|l|l|l|}
\hline Etiket (\#) & 30 & 5 & 20 & 55 \\
\hline
\end{tabular}

Kurumların hepsi paylaştığı iletilerde fotoğraf kullanmaktadır. Fotoğraftan başka sırasıyla bağlantı ve video ve etiket (\#) tercih edilmektedir. Sosyal medyada kurum kimliği yönetimi ile ilgili olarak, şirketlere yapılan önerilerden biri de paylaşılan iletilerde fotoğraf, video, etiket, bağlantı gibi multimedya içeriklerine yer verilmesi şeklindedir. Buna göre, analiz edilen şirketlerin büyük bir kısmı ileti paylaşımında bu içeriklere yer vermeleri noktasında sosyal medyayı doğru kullanmaktadır.

Facebook'a özgü olan bazı iletişim araçları bulunmaktadır. Bunlar uygulamalar, etkinlikler, notlar ve sayfanın beğendikleridir. $\mathrm{Bu}$ bilgiler istendiği takdirde sayfaya eklenebilir. Bu araçların kullanım düzeyi Tablo 7'de yer almaktadır. $\mathrm{Bu}$ araçlardan en çok tercih edileni uygulamalar olurken, en az tercih edileni etkinliklerdir.

Tablo 7. Facebook’a Özgü Araçların Kullanım Düzeyi

\begin{tabular}{|l|c|c|c|c|}
\cline { 2 - 5 } \multicolumn{1}{c|}{} & YÜKSEK & DÜŞÜK & YOK & TOPLAM \\
\hline Uygulamalar & 25 & 11 & 19 & 55 \\
\hline Etkinlikler & 10 & 1 & 44 & 55 \\
\hline Notlar & 17 & 3 & 35 & 55 \\
\hline $\begin{array}{l}\text { Sayfanın } \\
\text { beğendikleri }\end{array}$ & 21 & 10 & 24 & 55 \\
\hline
\end{tabular}

Özellikle etkinlikler bölümünün aktif olarak kullanılmaması önemli bir eksiklik olarak görülmektedir. Etkinlikler bölümünün yüksek düzeyde kullanılması şirketler ve hedef kitleleri arasında ilişki kurulması açısından önemlidir. Şirketler sayfalarında bu özelliği kullanarak yaptıkları etkinlikleri duyurabilir ve takipçilerinin katılımını sağlayabilirler. Notlar bölümü ile iletmek istedikleri uzun ve önemli mesajların sürekli sayfada yer almasını sağlayabilir, özel uygulamalar geliştirerek kullanıcılarının katılımını artırabilir ve kendisi ile ilişkili sayfaları beğenerek takipçilerini bu sayfalara yönlendirebilir. $\mathrm{Bu}$ bağlamda, incelenen sayfalar Facebook'a özgü araçları yüksek düzeyde kullanmanın getireceği avantajlardan faydalanmamaktadır. 
Kurumsal iletişim kategorisinden alınabilecek en yüksek puan 31'dir. 31 puan üzerinden kurumsal iletişim kategorisinde şirketlerden en yüksek puanı alan 24, en düşük puanı alan 6 puan almıştır. 55 şirketin bu kategorideki ortalama puanı 17,2 olarak hesaplanmıştır.

\subsection{Kurumsal Davranış ile İlgili Bulgular}

Kurumların Facebook hesaplarındaki davranışlarını ortaya çıkarmak amacıyla öncelikle, takipçileri ile kurdukları etkileşim düzeyleri ve kurumsal sosyal sorumluluk projelerine yer verip vermedikleri incelenmiştir. Kurumsal davranışın en önemli göstergelerinden biri de kurumların sosyal sorumluluk konusunda gerçekleştirdikleri faaliyetlerdir. Günümüzde her kurumun çevreye, topluma, çalışanlarına, müşterilerine ve tedarikçilerine karşı yerine getirmesi gereken sorumlulukları bulunmaktadır. Şirketlerin Facebook hesaplarında sosyal sorumluluk kampanyalarına yer verme oranları incelenmiş ve 35 gibi büyük sayıda şirketin bu konuda bir paylaşımda bulunmadığı, 4 tanesinin yalnızca bir kere 16 tanesinin birden fazla sosyal sorumluluk kampanyalarını paylaştığı görülmüştür.

Şirketlerin takipçileri ile ne düzeyde etkileşim kurduğunu ortaya çıkarmak amacıyla kullanıcıların sayfada paylaştıkları ve şirketin paylaştı̆̆ı iletilerin altına yorum olarak yazdıkları iletilerin kurumlar tarafından ne oranda beğenildiği ne oranda cevaplandığı, cevapların ne kadar sürede verildiği ve özel mesajlara cevap verme düzeyi incelenmiştir. Bunun sonucunda ortaya çıkan kullanıcılar ile etkileşim kurma düzeyleri Tablo 8'de görülmektedir.

Tablo 8. Kurumların Takipçileri ile Etkileşim Kurma Davranışları

\begin{tabular}{|l|c|c|c|c|}
\cline { 2 - 5 } \multicolumn{1}{l|}{} & YÜKSEK & DÜŞÜK & YOK & TOPLAM \\
\hline $\begin{array}{l}\text { Kullanıcıların sayfadaki } \\
\text { iletilerini beğenme }\end{array}$ & 11 & 4 & 40 & 55 \\
\hline $\begin{array}{l}\text { Kullanıcıların iletilerine } \\
\text { cevap verme }\end{array}$ & 16 & 12 & 27 & 55 \\
\hline $\begin{array}{l}\text { Iletilere cevap verme } \\
\text { süresi }\end{array}$ & 24 & 4 & 27 & 55 \\
\hline $\begin{array}{l}\text { Özel mesajlara cevap } \\
\text { verme }\end{array}$ & 21 & 3 & 27 & 51 \\
\hline
\end{tabular}


Takipçileri ile kurumlar arasındaki etkileşim düzeyi beklenen seviyede çıkmamıştır. Kurumlar genel olarak takipçilerinin iletilerini beğenme eğiliminde değildir. 40 şirket paylaşılan hiçbir iletiyi beğenmemiştir. Buna oranla, iletilere cevap verme düzeyi biraz daha yüksek bulunmuştur. 27 şirket takipçileri tarafindan sayfada paylaşılan iletilere cevap vermezken, 12 tanesi düşük, 16 tanesi yüksek oranda cevap vermektedir.

İletilere cevap verme süresi takipçilerin iletilerinin kısa veya uzun zaman aralığında cevaplanması ile ilgilidir. Aynı gün içerisinde cevap verildiğinde yüksek, bir gün veya daha sonra cevap verildiğinde düşük olarak kodlanmıştır. İletilere 24 şirket aynı gün içerisinde, 4 şirket, iletinin gönderildiği günden başka bir günde cevap vermiştir. 27 şirket hiçbir zaman cevap vermemiştir.

4 şirket özel mesaj gönderimine izin vermediği için özel mesajlara cevap verme düzeyi 51 şirket üzerinden değerlendirilmiştir. Araştırmacı 51 şirketin hepsine özel mesaj atmış ve cevap verip vermediklerine bakmıştır. Mesaja aynı gün içerisinde cevap veren şirketler 2 , daha sonra verenler 1 puan almıştır. Özel mesaj gönderilen şirketlerden 27 tanesi mesaja cevap vermemiş, 21 tanesi aynı gün içerisinde 3 tanesi daha sonra cevap vermiştir.

Şirketler tarafından takipçilerin sorularına, şikayetlerine, önerilerine ve beğenilerine nasıl cevap verildiği incelenen diğer bir unsurdur. 28 şirket takipçilerinin sayfasında paylaştı̆ğ iletilere cevap vermektedir. $\mathrm{Bu}$ nedenle cevapların içeriği 28 şirket üzerinden değerlendirilmiştir (Tablo 9).

Tablo 9. Kurumların Takipçilerine Verdiği Cevapların İçeriği

\begin{tabular}{|l|c|c|c|c|}
\cline { 2 - 5 } \multicolumn{1}{c|}{} & YÜKSEK & DÜŞÜK & YOK & TOPLAM \\
\hline Bilgilendirme & 10 & 12 & 6 & 28 \\
\hline Yönlendirme & 12 & 13 & 3 & 28 \\
\hline Bizimle iletişime geçin & 8 & 9 & 11 & 28 \\
\hline Empati/özür & 3 & 3 & 22 & 28 \\
\hline Onay/teşekkür & 5 & 11 & 12 & 28 \\
\hline
\end{tabular}

Şirketler cevap verirken en çok yönlendirme yapmayı tercih etmektedir. Takipçilerinin sorularına başka bir kaynağa (web sitesi, canlı destek hattı, müşteri hizmetleri) yönlendirme yaparak cevap vermiştir. Takipçilerin daha detaylı bilgi 
almaları için bu kaynaklara yönlendirmeyi tercih etmişlerdir. İkinci olarak, bilgilendirme yoluna gitmişlerdir. Yönlendirmeden farkı, istenen bilginin Facebook sayfasında ilgili sorunun altında verilmesi başka bir kanala yönlendirme yapılmamasıdır. Üçüncü olarak, kullanıcıların yaşadıkları problemlerin çözümü için bizimle özel mesaj, telefon veya e- posta aracılığıyla iletişime geçin, probleminizi ve iletişim bilgilerinizi iletin şeklinde cevap verilmektedir. Takipçilerin olumlu mesajlarına teşekkür edilme oranı, olumsuz mesajlara karşı özür dileme oranının üstünde çıkmıştır. Olumsuz mesajlara cevap vermek ve sorunları çözmeye çalışmak kurumsal imajın ve itibarın düzeltilmesini destekleyecek bir davranıştır. Şirketlerin bu avantajı yeteri kadar değerlendiremediği anlaşılmaktadır.

Kurumsal davranış kategorisi içerisinde değerlendirilen 10 değişken üzerinden yapılan kodlamaya göre en fazla 20 puan alınabilmektedir. Bu kategoride en yüksek puan 17 , en düşük puan 0 , ortalama 5,9'dur. 0 puana sahip 11 şirket bulunmaktadır. Bunun anlamı, 11 şirketin Facebook’ta takipçileri ile hiçbir etkileşim içerisinde bulunmamış ve sosyal sorumluluk kampanyasından bahsetmemiş olmasıdır. Bütün kategoriler içerisinde en düşük puan bu kategoride görülmüştür. $\mathrm{Bu}$ durum, en olumsuz yansitılan kurum kimliği unsurunun kurumsal davranış olduğu şeklinde yorumlanabilir.

\section{SONUÇ}

$\mathrm{Bu}$ çalışmada sosyal medyada kurum kimliği yönetiminin Fortune 500 şirketleri tarafından nasıl yapıldığı sorusu araştırılmıştır. Kurum kimliğini oluşturan kurum felsefesi, kurumsal tasarım, kurumsal iletişim ve kurumsal davranışa ilişkin unsurların hangilerinin ne düzeyde Facebook sayfalarında yansıtıldığı ayrı ayrı analiz edilmiştir. Kurum kimliği, her kuruluşun sahip olduğu ve ilişki içerisinde bulunduğu gruplara kendini ifade etmesinde en önemli unsurlardan birisidir. Kurumun istediği yönde algılanmasının ve kurum imajının öncülünü oluşturduğu için kurumsal iletişimin gerçekleştiği her ortamda kimliğin açık, tutarlı ve bütünleşik biçimde yansıtılması büyük önem taşımaktadır. Elde edilen bulgular ile şirketlerin Facebook'ta etkili bir kimlik yönetimi yapıp yapmadıkları ve kurum kimliği unsurlarının hangilerini ne düzeyde bu ortama yansıttıkları ortaya konmak istenmiştir. 
Şirketlerin Facebook sayfalarında kurum felsefesi unsurlarından en fazla kuruluş tarihine en az yöneticinin mesajı ve yönetici ile ilgili bilgilere rastlanmıştır. Bu durum Walczak ve Greg'in (2009: 25) kurumun üst yöneticileri ile ilgili bilgilerin Facebook ve LinkedIn'de giderek artan şekilde bulunduğunu ifade etmesine zit bir durum teşkil etmektedir. Çalışanların ve halkın zihninde kurum imajının inşa edilmesi için net bir biçimde bilinmesi ve anlaşılması gereken misyonun (Goodman: 2000: 70) sayfaların yarısında bulunmaması büyük bir eksiklik olarak görülmüştür.

Tuna ve Tuna (2007: 45) kurum felsefesine ilişkin unsurların yazılı ifadesinin kuruma katkı sağlayacağını belirtmiştir. Facebook kurumsal sayfa oluştururken misyon, kuruluşun tarihçesi, çalışma alanları, genel bilgiler, ödüller gibi hazır olarak sunduğu başlıklarla kurumsal kimlikle ilgili bilgilerini eklemeleri için imkan sunmakta ve gerekli alanı yaratmaktadır. Ancak bu alanın misyon, vizyon, hedefler, değerler ve yöneticilerle ilgili bilgileri aktarma konusunda yeterince etkin kullanılmadığı görülmektedir.

Kurumsal kimliğin en fazla görünen unsuru olan logolar incelenen sayfalardan bir tanesi hariç diğer hepsinde yer almaktadır. Genellikle profil fotoğrafi olarak tercih edilmekte ve paylaşılan iletilerdeki görsellere eklenmektedir. Şirketlerin logolarını profil fotoğrafı olarak kullanmaları doğru ve önerilen (Postman, 2009: 87) bir uygulamadır. Bazı şirketler logo yerine profil fotoğrafında amblem kullanmayı tercih etmiştir. Kurumsal renklerini şirketlerin büyük çoğunluğu sayfalarına taşırken, slogana yer verilme oranı neredeyse yarı yarıyadır.

Şirketlerin çevre ve ürün tasarımı unsurları içinde en fazla ürün/hizmet görsellerini kullandıkları tespit edilmiştir. Bunun yanında eşit sayılabilecek bir oranda çalışanların ve çalışma alanlarının görselleri ve bunlara göre biraz daha düşük bir oranda şirket binasının görselleri paylaşılmıştır. Bu bulgulardan şirketlerin ürün ve hizmetlerini tanıtmak amacıyla Facebook'u yeterince etkin bir biçimde kullandığ sonucuna ulaşılabilir.

Kurumların iletişim kanalı olarak en çok web sitesi bağlantılarına sayfalarında yer verdikleri ortaya çıkmıştır. Bu durum, kurumsal iletişimde hala en önemli araç olarak web sitelerinin görüldüğünü düşündürtmektedir. En çok bağlantı 
verilen sosyal medya hesapları sirasıyla Twitter, YouTube ve Instagramdır. Bu durum, bu sosyal ağların Türkiye'deki kullanıcı sayıları ile paralellik göstermektedir.

Kurumların iletilerinde hangi içeriklerin yer aldığı sorusunun sonucunda, en çok fotoğraf, daha sonra sırasıyla diğer sanal iletişim kanallarına bağlantı, video ve etiket cevapları ortaya çıkmıştır. Bu multimedya içeriklerinin iletilerde yüksek oranda kullanımı ve kurumların ileti paylaşım sıklıkları kurumlar açısından olumlu olarak değerlendirilen noktalardandır. Diğer yandan, Facebook'a özgü etkinlikler, notlar sekmesi gibi araçların aktif olarak kullanılmayışı ve şirketlerin sayfalarında Facebook kullanıcılarının ileti, fotoğraf ve video paylaşmasına çoğunlukla izin vermemesi olumsuz olarak değerlendirilmiştir.

Kurumsal davranışın sosyal medyada nasıl yönetildiği kurumların takipçileri ile kurduğu etkileşimin düzeyine bakılarak tespit edilmiştir. Elde edilen bulgulara göre, kurumların takipçileri ile etkileşim kurma düzeyleri oldukça düşüktür. Sosyal medyanın en önemli özelliği olan etkileşim boyutu kurumlar tarafından etkili bir şekilde değerlendirilememiştir. Aynı zamanda, kurumların yarısı kullanıcıların sayfada ve özel mesajda soru, yorum, şikayet gibi paylaşımlarına hiçbir cevap vermemektedir. Bu davranışlar, kurumlar açısından olumsuz sonuçlara yol açabilme potansiyeline sahip olduğu için dikkat edilmesi gereken bir durumdur.

Kurum kimliğini oluşturan dört unsurdan alınan ortalama puanlara bakıldığında, kurumsal tasarım ve kurumsal iletişim boyutlarında, kurum felsefesi ve kurumsal davranış boyutlarına oranlara daha yüksek puanlar dikkati çekmektedir. Kurum kimliğinin çekirdeğinde yer alan kurum felsefesi ile ilgili unsurların yansıtılması ve olumlu bir kurumsal davranışın sergilenmesi konusunda şirketlerin eksikliklerinin bulunduğu söylenebilir.

\section{KAYNAKÇA}

BARNES, N. G.; LESCAULT, A. M.; WRİGHT, S. (2013). Fortune 500 are bullish on social media: Big companies get excited about Google+, Instagram, Foursquare

and

Pinterest.https://www.umassd.edu/media/umassdartmouth/cmr/studiesandrese arch /2013_Fortune_500.pdf (Erişim tarihi: 23.06.2015) 
BICK, Geoff; JACOBSON, Marciene C.; ABRATT, Russell (2003). The Corporate Identity Management Process Revisited. Journal of Marketing Management, 19 (7-8), 835-855.

CASTRONOvO, Cristina ve HUANG, L. (2012). Social Media in an Alternative Marketing Communication Model. Journal of Marketing Development and Competitiveness, 6(1), 117-131.

DOLPHIN, Richard R. (1999). The Fundamentals of Corporate Communications. Oxford: CIM/Butterworth-Heinemann.Competitiveness, 6(1), 117-131.

ERDOĞAN, İrfan (1998). Spss Kullanım Örnekleriyle Araştırma Dizaynı ve İstatistik Yöntemleri. Ankara: Emek Matbaası.

GILPIN, Dawn (2010). Organizational Image Construction in a Fragmented Online Media Enviroment. Journal of Public Relations Research, 22 (3), 265-287.

GOODMAN, Michael B. (2000). Corporate Communication: The American Picture. Corporate Communications: An International Journal, 5 (2), 69-74.

GÖKÇE, Orhan (2001). İçerik Çözümlemesi: Teori-Metod-Uygulama. (3. Bask1). Konya: Selçuk Üniversitesi.

KADIBEŞEGİL, Salim (2007). İtibar Yönetimi: İtibarınızı Yönetmekten Daha Önemli Bir İşiniz Var Mı? (3. Bask1). İstanbul: MediaCat.

KAPLAN, Andreas M. ve HAENLEIN, Michael (2010). Users Of The World, Unite! The Challenges And Opportunities Of Social Media. Business Horizons, 53(1), 59-68.

KOSTAMO, Uuna (2013). The New Era Of Corporate Marketing: Building And Managing Corporate Identity in Social Media. Yayınlanmamış Yüksek Lisans Tezi. Finlandiya: Aalto Üniversitesi.

MARKWICK, Nigel ve FILL, Chris (1997). Towards A Framework For Managing Corporate Identity. European Journal of Marketing, 31 (5/6), 396-409. 
MELEWAR, T. C. (2003). Kurumsal Kimlik İnşasını Belirleyen Faktörler: Bir Literatür Taraması. (Çev: Zeliha Hepkon). İstanbul Ticaret Üniversitesi Dergisi, 2 (4), 175-211.

MELEWAR T. C. ve KARAOSMANOĞLU, Elif (2006). Seven Dimensions of Corporate Identity: A Categorisation From The Practitioners. European Journal of Marketing, 40 (7/8), 846-869.

NEUMAN, W. Lawrence (2008). Toplumsal Araştırma Yöntemleri Nicel ve Nitel Yaklaşımlar 2. Cilt. (2. Baskı). İstanbul: Yayınodası.

OKAY, Ayla (2013). Kurum Kimliği. (7. Bask1). İstanbul: Derin Yayınları.

POINDEXTER, Paula M. ve McCOMBS, Maxwell E. (2000). Research in Mass Communication: A Practical Guide. Boston: Bedford/St. Martin's.

POSTMAN, Joel (2009). SocialCorp: Social Media Goes Corporate. Berkeley, CA: Peachpit Press.

RYAN, Damian (2014). Understanding Digital Marketing: Marketing Strategies For Engaging The Digital Generation. (3. Bask1). United Kingdoom: Koganpage.

SAFKO, Lon (2012). The Social Media Bible. New Jersey: John Wiley and Sons.

THEAKER, Alison (2006). Halkla İlişkilerin El Kitabı. (Çev: M. Yaz). İstanbul: MediaCat.

TOPALIAN, Alan (2003). Experienced Reality: The Development of Corporate Identity in the Digital Era. European Journal of Marketing, 37 (7/9), 11191132.

TUNA, Muharrem ve TUNA, Ayşen (2007). Kurumsal Kimlik Yönetimi. Ankara: Detay Yayınları.

VAN DEN BOSCH, Anette L. M.; ELVING, Wim J. L; DE JONG, Menno D. T. (2006). The Impact Of Organisational Characteristics On Corporate Visual Identity. European Journal of Marketing, 40 (7/8), 870-885. 
Sosyal medyada kurum kimliği yönetimi: Türkiye’nin...

VAN RIEL, C. B. Maria ve FOMBRUN, Charles (2007). Essentials Of Corporate Communication: Implementing Practices For Effective Reputation Management. London: Routledge.

WALCZAK, Steven ve GREGG, Dawn (2009). Factors Influencing Corporate Online Identity: A New Paradigm. Journal of Theoretical and Applied Electronic Commerce Research, 4 (3), 17-29. 